\title{
CHARACTERISTIC OF HOSPITALIZED BURN INJURY PATIENTS IN ZAINOEL ABIDIN GENERAL HOSPITAL YEAR 2016-2017
}

\author{
Syamsu Rizal, Muhammad Jailani, Mirnasari Amirsyah, \& Emil Muzzamil \\ Division of Plastic Surgery, Zaionoel Abidin General Hospital, Universitas Syoah Kuala, Aceh, Indonesia.
}

\begin{abstract}
Background: The epidemiology pattern of patients with burn injury varies widely in different parts of the world. This study aimed to identify epidemiological data from hospitalized burn injury patients in Zainoel Abidin General Hospital, a referral Hospital in Aceh.

Methods: All hospitalized burn injury patient data from January 2016 to December 2017 were collected from the medical record. Data taken included Gender, age, length of stay (LOS), mortality, severity, and extent of the burn, and etiology of burn.

Results: From all hospitalized patients with burn injury, the male to female ratio is $1,6: 0,9$. The mortality rate is $9 \%$, while the others survive. From all etiology of burn, $57 \%$ is flame injury, $19 \%$ is electrical injury, $18 \%$ is scald burn injury, $4 \%$ is contact burn injury, and $1 \%$ is a chemical burn injury. No patient with first-degree burns was hospitalized, while 13 patients had third-degree burn injuries, and the rest had second-degree burn injuries.

Conclusion: An increasing number of hospitalized patients from 2016 to 2017, from 25 patients to 42 patients. It might happen because of increasing knowledge about burn injury in society and physicians in rural areas to refer patients to the hospital with better facilities.
\end{abstract}

Keywords: Burn; Epidemiology; Thermal Injury; Flame Injury.

Latar Belakang: Pola epidemiologi pasien dengan luka bakar berbeda diseluruh penjuru dunia. Tujuan penelitian ini adalah untuk mengetahui data epidemiologi pasien luka bakar yang dirawat inap di Rumah Sakit Umum Daerah Zainoel Abidin sebagai Rumah Sakit rujukan Provinsi Aceh.

Metodologi: Semua data pasien luka bakar yang dirawat inap dari Januari 2016 sampai dengan Desember 2017 dikumpulkan dan ditilik melalui rekam medis. Data yang diambil meliputi jenis kelamin, umur, ama rawatan, mortalitas, kedalaman dan luas luka bakar serta etiologic luka bakar.

Hasil: Dari keseluruhan pasien luka bakar yang dirawat inap, rasio laki-laki dan perempuan adalah 1,6:0,9. Tingkat mortalitas adalah $9 \%$, sedangkan pasien lainnya dapat sembuh dengan baik. Dari keseluruhan etiologi luka bakar, $57 \%$ adalah karena luka bakar api, 19\% adalah luka bakar listrik, 18\% adalah luka bakar cairan panas, 4\% adalah luka bakar kontak dan $1 \%$ luka bakar kimia. Berdasarkan data yang dikumpulkan, tidak ada pasien dengan luka derajat 1 yang dirawat, sementara 13 pasien dengan luka bakar derajat 3, dan sisanya adalah derajat 2.

Kesimpulan: terdapat peningkatan pasien yang dirawat inap dari tahun 2016 ke tahun 2017, yaitu dari 25 pasien menjadi 42 pasien. Hal ini terjadi dikarenakan peningkatan pengetahuan dan upaya edukasi tentang luka bakar pada khalayak umum dan dokter di daerah untuk merujuk pasien ke rumah sakit yang memiliki fasilitas yang lebih baik.

Kata Kunci: Luka Bakar; Epidemiologi; Trauma Panas; Trauma Api

Conflicts of Interest Statement:

The author(s) listed in this manuscript declare the absence of any conflict of interest on the subject matter or materials discussed. 


\section{INTRODUCTION}

Burns is one of the injuries caused by trauma. The incidence rate and mortality rate are varied around the world. Every year, around 180.000 death was caused by burns injury, most of which happened in developing countries ${ }^{1}$. In a developing country, most burn injuries happened in rural areas. The etiology of burn injury is flame while refilling fuel into a stove ${ }^{2}$. Meanwhile, burn injuries in a developed country more often happened in an urban area than in rural areas, and the most frequent etiology is scalded burns injury from hot liquids ${ }^{3}$.

Zainoel Abidin General Hospital (RSUDZA) is the main referral hospital in Aceh province. There are no burn units available in Aceh Province, even in RSUDZA, which become a problem in burn injury care. There is no published epidemiological data for a burn injury in RSUDZA and Indonesia. This study aims to know the characteristic of hospitalized burn injury patients to improve burn care. Other goals are to identify length of stay (LOS) rate, mortality, severity, and extent of burn injury etiology in RSUDZA.

\section{METHOD}

This is a retrospective study; the subjects were all patients with burns injury hospitalized in RSUDZA from January 2016 to December 2017. All data were retrospectively collected from the medical records. Data taken from the medical records included Gender, age, etiology, severity, and extent of the burn, Los, and laboratory tests such as Hemoglobin, Leucocyte, and Thrombocyte Level. Burn severities were classified as: Grade 1 is Superficial Thickness Burn Injury, which only affects the epidermis. Grade 2 is Partial Thickness Burn Injury, which affected the dermis Grade 3 is Full Thickness Burn Injury, which affected underneath dermis tissue. Extent of burns injury were calculated from the percentage of total burn surface area (TBSA), which classified as: TBSA $\leq 10 \%$; TBSA between $11 \%$ to $30 \%$; TBSA from $31 \%-50 \%$; TBSA between $51 \%$ and $70 \%$; and TBSA $\geq 71 \%$. The severity and extent of burns injury was diagnosed with a physical examination by experienced surgeons.

\section{RESULTS}

A total of 67 patients were admitted from January 2016 to December 2017. Demographics, Los, mortality, burn characteristics, and also etiology are shown in Table 1 . There is an increase of burn case in $2017(n=42)$ compared to 2016 ( $n$ $=25)$. Male $(n=43)$ were more dominant compared to female $(n=24)$, with male to female ratio is 2:1.1. The average LOS from 2016 to 2017 is 28 days.

The amount of $2^{\text {nd }}$ degree burn injury decreased from $92 \%(n=23)$ in 2016 to $74 \%(n=$ 31 ) in 2017. Meanwhile, for $3^{\text {rd }}$ degree burn injury case increased from $8 \%(n=2)$ in 2016 to $26 \%(n=$ 11 ) in 2017 . There are no patients hospitalized for $1^{\text {st }}$ degree burn injury.

Burn injury with TBSA $<10 \%$ increased from $12 \%(n=3)$ in 2016 to $36 \%(n=15)$ in 2017, burn injury with TBSA $11-30 \%$ decreased from $12 \%(n=15)$ in 2016 to $26 \%(n=11)$ in 2017 , burn injury with TBSA $31-50 \%$ increased from $12 \%$ ( $n$ $=3)$ in 2016 to $31 \%(n=13)$ in 2017 , burn injury with TBSA $51-70 \%$ decreased from $16 \%(n=4)$ in 2016 to $5 \%(n=2)$ in 2017 , burn injury with TBSA $>71 \%$ slightly increased to $2 \%(n=1)$ in 2017 .

Most case of burn caused by flame burn both in 60\% $(n=15)$ in 2016 and 55\% $n=23)$ in 2017 , burn caused by scald burn decreased from $28 \%(n=7)$ in 2016 to $11 \%(n=5)$ in 2017 . Mortality rate increased from $4 \%(n=1)$ to $11 \%(n$ $=5$ ) in 2017 , death to survival ratio is 1:10.1 case.

\section{DISCUSSION}

This is the first published study examining burn injury epidemiology in Zainoel Abidin General Hospital, Aceh Province. To date, in Indonesia, there is no published epidemiology study of burn injury patients.

The increasing number of hospitalized patients in 2017 can be related to the new Indonesian Health Insurance Policy, of which all burn injury must be referred to as the type A hospital, which is only RSUDZA in Aceh. Meanwhile, the reimbursement rate was too low in the lower type of hospital regarding its facilities, so burn injury patients cannot be treated. 
Table 1. Characteristics of hospitalized burn injury patients in Zainoel Abidin General Hospital year 20162017

\begin{tabular}{|c|c|c|c|}
\hline Characteristics & $\begin{array}{l}2016 \\
\mathrm{n}(\%)\end{array}$ & $\begin{array}{l}2017 \\
\mathrm{n}(\%)\end{array}$ & $\begin{array}{l}\text { Total } \\
\mathrm{n}(\%)\end{array}$ \\
\hline \multicolumn{4}{|l|}{ Sex } \\
\hline Male & $12(48)$ & $31(74)$ & $43(64)$ \\
\hline Female & $13(52)$ & $11(26)$ & $24(36)$ \\
\hline \multicolumn{4}{|l|}{ Severity } \\
\hline $1^{\text {st }}$ Degree & 0 & 0 & 0 \\
\hline 2nd Degree & $23(92)$ & $31(74)$ & $54(80)$ \\
\hline 3rd Degree & $2(8)$ & $11(26)$ & $13(20)$ \\
\hline \multicolumn{4}{|l|}{ TBSA } \\
\hline $0 \%-10 \%$ & $3(12)$ & $15(36)$ & $18(27)$ \\
\hline $11 \%-30 \%$ & $15(60)$ & $11(26)$ & $26(39)$ \\
\hline $31 \%-50 \%$ & $3(12)$ & $13(31)$ & $16(24)$ \\
\hline $51 \%-70 \%$ & $4(16)$ & $2(5)$ & $6(9)$ \\
\hline $71 \%-100 \%$ & 0 & $1(2)$ & $1(1)$ \\
\hline \multicolumn{4}{|l|}{ Outcome } \\
\hline Survive & $24(96)$ & $37(88)$ & $61(91)$ \\
\hline Death & $1(4)$ & $5(12)$ & $6(9)$ \\
\hline \multicolumn{4}{|l|}{ Etiology } \\
\hline Scald & $7(28)$ & $5(12)$ & $12(18)$ \\
\hline Flame & $15(60)$ & $23(55)$ & $38(57)$ \\
\hline Electrical & $2(8)$ & $11(26)$ & 13(19) \\
\hline Contact & $1(4)$ & $2(5)$ & $3(5)$ \\
\hline Chemical & 0 & $1(2)$ & $1(1)$ \\
\hline
\end{tabular}

The male to female ratio is 2:1.1 case, similar to another epidemiological study. ${ }^{3-6}$ However, one study showed predominantly female burns, injury patients. This difference can be caused by variation in ethnic tradition, cultural background, and socio-economic background of each country. $^{2}$

The mean LOS in this study is 28 days. High LOS in this study is caused by the regulation of Indonesian National Health Insurance in which cannot be claimed twice for the same diagnoses in one month. Because of that, all hospitalized patients are required to be fully recovered before discharged. Meanwhile, some patients require more than one debridement surgery to recover fully. One of our patients needs 113 days to be fully recovered and released from contracture. This makes Los very high in our hospital. This phenomenon also occurred in Israel7 ${ }^{7}$ with mean LOS was 38,7 days, but they did not evaluate why this phenomenon happened. Another study by Bartosch et al. showed slightly different LOS from our study, 24,7 days. ${ }^{8}$ There are correlation from

Higher LOS with higher severity and extent of the burn, patients with severe lesions have a higher mortality rate in the first days of hospitalization, but they have longer LOS if they survive.

Second-degree burn injury decreased from $92 \%$ in 2016 to $74 \%$ in 2017. However, thirddegree burn injury increased from $8 \%$ in 2016 to $26 \%$ in 2017; increasing electrical burn injury cases caused this increase. Cho et al. reported there is a higher incidence of a deep burn than a superficial burn. ${ }^{9}$ High incidence of deep burn mostly caused by contact burn; patients with 
contact burn has 4.26 times higher risk of thirddegree burns injury. ${ }^{9}$

The mortality rate was increasing in 2017 due to increasing hospitalized patients. In 2017, death to survival ratio was 1:10.1. All mortality patients in our hospital related to bloodstream infection (BSI) and high \%TBSA affected. Our hospital still used conventional methods to diagnose sepsis patients without a specific marker. 4 out of 6 non-survivors $(n=66,6 \%$ ) have leucocyte levels $>12.000$. The major referral hospital in Colombia also reported six patients with an infection that lead to death, but their study cannot define the relationship between sepsis in burn injury to cause of death due to the small amount of sample. ${ }^{10}$ Another study reported that mortality in burn injury related to nosocomial infection. ${ }^{8}$

Based on the data about death patients with burn injury, $50 \%$ are male, and another $50 \%$ is female. This is similar to another study in Iran; they found that the mortality rate was equal in both genders in 1991. ${ }^{11}$ Ederer et al. also showed no relevant gender-specific differences in burn mortality. ${ }^{12}$ However, another study found different mortality rates in the specific Gender, mostly are male. ${ }^{13-15}$

Four out of six non-survivor patients are less than five years old or more than 60 years old. Geriatric patients have a higher risk of mortality than productive age due to immunological response. ${ }^{16}$ Farinas et al. found that CCL5 (also known as Regulated on Activation of Normal T Cell Expressed and Secreted or RANTES) and EGV (Epidermal Growth Factor), which is chemokine and cytokines that play a role in wound healing to increasing angiogenesis, are lower in geriatric than productive age population. ${ }^{16}$ This explains why the elderly have a higher risk of mortality than productive aged patients. Meanwhile, the child population also has a high risk of mortality; this is caused by less attention or awareness of the parents, making them prone to burn source. World Health Organization (WHO) reported that children in low-income countries to have eleven times higher mortality rates than middle-income countries. ${ }^{17}$ High mortality in children has no clear evidence. We suggest that children have immature immunology in response to injury.

Three out of six $(n=50 \%)$ patients have $>50 \%$ TBSA affected with burn. Almost all research linked greater TBSA with a higher incidence of bloodstream infection (BSI). $7,10,18$ Greater TBSA requires more surgical procedures like escharotomy or fasciotomy, impacting the increasing rate of infection.

More than half of hospitalized patients had etiology of flame burn in 2016 and 2017 (respectively $60 \%(n=15)$ and $55 \%(n=23))$. This also happened in Tanzania, where more than half of patients have flame burn injury as etiology of burn. ${ }^{19}$ This can be correlated to the patient's job. Most of the male patients work outdoor while female work at home (indoor). A flame burn injury can be related to an explosion of kerosene or an explosion of gasholder.

\section{CONCLUSION}

This study is a preliminary study to analyze hospitalized burn injury patients in RSUDZA. There are amount of increasing hospitalized patients in 2017 due to the policy of Indonesian National Health Insurance. The most cause of burn injury in our hospital is a flame burn injury. The mortality rate also increased in 2017.

\section{Correspondence regarding this article should be addressed to:}

Syamsul Rizal, Division of Plastic Surgery, Zaionoel Abidin General Hospital, Universitas Syoah Kuala, Aceh, Indonesia.

E-Mail: sy.rizal@unsyiah.ac.id

\section{REFERENCES}

1. World Health Organization. Burns [Internet]. 2018. Available from: www.who.int/news-room/factsheets/detail/burns

2. Ganesamoni S, Kate V, Sadasivan J. Epidemiology of hospitalized burn patients in a tertiary care hospital in South India. Burns. 2010;

3. Vidal-Trecan G, Tcherny-Lessenot S, Gross C, Devaux S, Pages $M$, Laguerre J, et al. Differences between burns in rural and in urban areas: implications for prevention. Burns [Internet]. 2000 Jun 1;26(4):351-8. Available from: https://doi.org/10.1016/S03054179(99)00175-8 
4. Zayakova Y, Vajarov I, Stanev A, Nenkova N, Hristov H. Epidemiological analysis of burn patients in East Bulgaria. Burns [Internet]. 2014 Jun 1;40(4):683-8. Available from:

https://doi.org/10.1016/j.burns.2013.08.01 6

5. Song C, Chua A. Epidemiology of burn injuries in Singapore from 1997 to 2003. Burns. 2005;

6. Kobayashi K, Ikeda H, Higuchi R, Nozaki M, Yamamoto Y, Urabe $\mathrm{M}$, et al. Epidemiological and outcome characteristics of major burns in Tokyo. Burns. 2005;

7. Raz-Pasteur A, Hussein K, Finkelstein R, Ullmann Y, Egozi D. Blood stream infections (BSI) in severe burn patients\&\#x2014;Early and late BSI: A 9-year study. Burns [Internet]. 2013 Jun 1;39(4):636-42. Available from:

https://doi.org/10.1016/j.burns.2012.09.01 5

8. Bartosch I, Bartosch C, Egipto P, Silva Á. Factors associated with mortality and length of stay in the Oporto burn unit (2006\&\#x2013;2009). Burns [Internet]. 2013 May 1;39(3):477-82. Available from: https://doi.org/10.1016/j.burns.2012.07.02 3

9. Cho YS, Choi YH, Yoon C, You JS. Factors affecting the depth of burns occurring in medical institutions. Burns [Internet]. 2015 May 1;41(3):604-8. Available from: https://doi.org/10.1016/j.burns.2014.09.00 8

10. Ramirez-Blanco $\mathrm{CE}$, Ramirez-Rivero $\mathrm{CE}$, Diaz-Martinez LA, Sosa-Avila LM. Infection in burn patients in a referral center in Colombia. Burns [Internet]. 2017 May 1;43(3):642-53. Available from: https://doi.org/10.1016/j.burns.2016.07.00 8

11. Sadeghian F, Saeedi Moghaddam S, Saadat S, Niloofar P, Rezaei N, Amirzade-Iranaq $\mathrm{MH}$, et al. The trend of burn mortality in Iran \&\#x2014; A study of fire, heat and hot substance-related fatal injuries from 1990 to 2015. Burns [Internet]. 2018 Oct 28; Available from:

https://doi.org/10.1016/j.burns.2018.09.00 6
12. Ederer IA, Hacker $S$, Sternat N, Waldmann A, Salameh O, Radtke C, et al. Gender has no influence on mortality after burn injuries: A 20-year single center study with 839 patients. Burns [Internet]. 2018 Oct 28; Available from:

https://doi.org/10.1016/j.burns.2018.08.01 2

13. Fan $X$, Ma B, Zeng D, Fang X, Li H, Xiao S, et al. Burns in a major burns center in East China from 2005 to 2014: Incidence and outcome. Burns [Internet]. 2017 Nov 1;43(7):1586-95. Available from: https://doi.org/10.1016/j.burns.2017.01.03 3

14. Mashreky SR, Shawon RA, Biswas A, Ferdoush J, Unjum A, Rahman AKMF. Changes in burn mortality in Bangladesh: Findings from Bangladesh Health and Injury Survey (BHIS) 2003 and 2016. Burns [Internet]. 2018 Sep 1;44(6):1579-84. Available from: https://doi.org/10.1016/j.burns.2018.01.00 9

15. Wanjeri JK, Kinoti M, Olewe THAM. Risk factors for burn injuries and fire safety awareness among patients hospitalized at a public hospital in Nairobi, Kenya: A case control study. Burns [Internet]. 2018 Jun 1;44(4):962-8. Available from: https://doi.org/10.1016/j.burns.2017.11.00 7

16. Farinas AF, Bamba R, Pollins AC, Cardwell NL, Nanney LB, Thayer WP. Burn wounds in the young versus the aged patient display differential immunological responses. Burns [Internet]. 2018 Sep 1;44(6):1475-81. Available from: https://doi.org/10.1016/j.burns.2018.05.01 2

17. World Health Organization. Children and burns [Internet]. 2004. Available from: http://www.who.int/violence_injury_prev ention/child/en/

18. Fochtmann-Frana A, Freystätter C, Vorstandlechner V, Barth A, Bolliger M, Presterl E, et al. incidence of risk factors for bloodstream infections in patients with major burns receiving intensive care: A retrospective single-center cohort study. Burns [Internet]. 2018 Jun 1;44(4):784-92. Available 
https:/ / doi.org/10.1016/j.burns.2017.12.00 9

19. Ringo Y, Chilonga K. Burns at KCMC:
Epidemiology, presentation, management and treatment outcome. Burns. 2014;40:1024-9. 